\title{
Pragmatics of fraus: Encoding and Decoding of Deceit in Seneca's Troades and Thyestes
}

\author{
Lavinia Scolari
}

$\mathbf{1}$

Introduction

The Latin language has a broad range of words covering the semantic area of 'deception' and 'trick'. 'Among them, fraus occupies a central position in the dramaturgical contexts as a recurring pattern of tragic plots. ${ }^{2}$ Scholars have pointed out that it expresses the general notion of deceit but also the concept of 'harm through deception'. In fact, the basic meaning of fraus is 'injury' or 'damage' (malum, quod quis facit uel patitur, damnum, iniuria), as the connection to

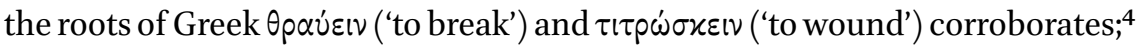
therefore, fraus is a 'detriment' that implies a certain measure of 'fraudulent responsibility'. In other words, it denotes a 'deceit' or a 'stratagem', 5 in which the notio nocendi ('the notion of doing harm') prevails and it comprises conducts involving guilt which are therefore liable to punishment: accedit quod iniuria fallendo fit ('it occurs that one commits an outrage by deceiving'). ${ }^{6}$

Frequently, fraus is combined with dolus, especially in non-legal texts, where they are, to some extent, interchangeable (one need only think that fraus corresponds to dolus malus in ThLL's definition). ${ }^{7}$ Nevertheless, they represent independent concepts: the former conveys the notion of 'damage' or 'harm' (like in the expression sine fraude), confirming its strictly negative (moral) sense; by contrast, the latter, which communicates the idea of 'malicious intent' (like in the expression dolo malo, 'evil device' or 'artifice', hence 'fraud', 'deceit'), ${ }^{8}$ may also have a positive connotation, even if the negative sense is predominant. According to Isidorus (Etym. 5.26.7), dolus is said to be

1 Abbot (1997:42 n.1) gives a list of the most common words associated with trickery and deceit. See also Brotherton (1926); Carcaterra (1970: 32); Wheeler (1988: 50-92).

2 See Michelon (2015: 17-71).

3 Brotherton (1926: 9); Ernout and Meillet ( ${ }^{4} 1985$ : s.v. fraus).

4 Rubenbauer (1926: c. 1267); Wheeler (1988: 63), who refers to Krüger and Kaser (1943).

5 Wheeler (1988: 50-52, 63-65).

6 Rubenbauer (1926: c. 1267, 1269). See also OLD, s.v. fraus, 1-4, p. 732.

7 Rubenbauer (1926: c. 1267). On dolus in juridical context, see Ter Beek (1999).

8 Wheeler (1988: 58). On the difference between dolus bonus and dolus malus, see Carcaterra (1970).

(C) LAVINIA SCOLARI, $2021 \mid$ DOI:10.1163/9789004440265_020

This is an open access chapter distributed under the terms of the CC BY-NC-ND 4.olicense. Scolari - 9789004440265 
from deludere (ab eo quod deludat), i.e. 'to play false', 'to mock', 'to deceive', and it consists in 'a cunning of the mind' (est mentis calliditas), or-as we should say-in its effects. ${ }^{9}$ Therefore, we can argue that the agent of dolus is able 'to play false' or 'deceive' in so far as he 'does one thing and fakes another' (aliud enim agit et aliud simulat) as stated by Isidorus (ibid.). ${ }^{10}$ Hence, as is stressed by Cicero (Off. 3.64) as well, dolus - especially dolus malus -intertwines itself with the concepts of simulatio and dissimulatio, which fall within a similar semantic field. In fact, simulatio is 'a falsely assumed appearance' or 'insincerity, deceit':11 a kind of pretence regarding physical or mental states, although the first meaning of this word more generally refers to an act of copying or imitation..$^{12}$ While the semantic bonds between dolus and simulatio/simulare as well as between fraus and dolus are mostly explicit, the link between fraus and simulatio is not. But in the tragic context of fraudulent imitation (of an attitude, a feeling, etc.), their bond becomes more evident, as it is the case in Seneca's tragedies, on which we will focus in this survey.

More specifically, we will explore the most relevant strategies of encoding and decoding of deceits in Seneca's Troades and Thyestes (which both show significant correlations, as we will try to illustrate further below) from a pragmatic, dramaturgical, and anthropological point of view, in the belief that such an interdisciplinary approach may provide a more comprehensive and detailed framework of the practice and the meaning of deception in Seneca's theatre and, more generally, in Roman culture. In this regard, we will follow the research methodology developed by Licinia Ricottilli and her school, who have successfully applied pragmatics to Classical Studies, combining them with the anthropological survey tools. ${ }^{13}$ Using this approach, we shall take the traditionally assumed — not incorrect, but only partly adequate - meaning of the term fraus (discussed below) as a starting-point; ultimately, we shall attempt to provide a more accurate definition of fraus, that takes Roman cultural categories into account that are involved in the communication dynamics portrayed by Seneca.

$9 \quad$ For this translation, we follow Barney et al. ( $\left.{ }^{4} 2008\right)$.

10 See Hey (1910: c. 1857) and OLD, s.v. dolus. See also Ulp. Dig. 2.14.7.9 dolus malus fit calliditate et fallacia.

11 Lewis and Short (1879: s.v. simulatio).

12 OLD, s.v. simulatio 1-2. See also OLD, s.v. simulo.

13 See Ricottilli (2000, 2009, 2011, 2018b: 7-19), who relies on Austin $\left({ }^{2} 1975\right)$; Watzlawick et al. (1967); Searle (1969); Bateson (1972). For a combination of anthropological and pragmatic approaches, see also Bettini and Ricottilli (1987); Duranti (1997); Beta (2004); Raccanelli (1998, 2010, 2011). On Seneca's tragedies (specifically on Phaedra), see Calabrese (2007, 2009, 2011). 


\section{$2 \quad$ Pragmatics of fraus in Troades}

\subsection{First Phase: The Concealment}

Seneca's Troades provides us with a very relevant case of (unsuccessful) deceit performed by Andromache. The plot of the play, mainly based on Euripides' Trojan Women and Hecuba, is well known: Troy has already fallen and the Trojan women are waiting to be assigned to the Achaean leaders. But, according to the herald Talthybius, the ghost of Achilles has returned from the Underworld to demand that the Trojan princess Polyxena be sacrificed at his tomb. The prophet Calchas, once consulted by Agamemnon, adds that Hector's son, Astyanax, must be slain too. Only then will the Greeks be able to return home. But meanwhile, the ghost of Hector appears in Andromache's dream and warns her of the danger. So, she orchestrates a fraud consisting in hiding her son in Hector's grave and pretending that he is dead in order to deceive Ulysses, who has been sent to hand over the child to the Achaeans.

Euripides' tragedy on the same subject lacks the entire scene of fraus as well as the agon between Andromache and Ulysses, which we shall discuss below. Actually, in Greek Trojan Women, Talthybius informs Hector's widow of the Achaeans' decision when Ulysses has already ordered to lead her son away (709-779). Hence, we can argue that Seneca's representation of this fraus conveys some aspects of the deceit dynamic closely interrelated with the Roman cultural categories of that time, which makes it particularly significant for our survey.

In Seneca's Troades, when Andromache first comes onto the stage, the only reason for keeping the Greeks from leaving is Astyanax, because of the danger he poses, since he is Troici defensor et uindex soli, 'Troy's defender and avenger' (471): being not only a future enemy to the Achaeans but also the potential uindex of his land, magni certa progenies patris, 'the true child of his great father' (461), and hence una spes Phrygibus, 'sole hope of the Phrygians' (462).

Therefore, Andromache needs to find a place where she can hide him:

\section{[1] Seneca Troades 476-477}

heu me, quis locus fidus meo

erit timori quaue te sede occulam?

O what place will not betray my fear, in what shelter shall I hide you? ${ }^{14}$

14 For the text and the translation of Seneca's Troades, we follow Boyle (1994), except where otherwise noted. 


\section{[2] Seneca Troades 481-482}

superestque uasta ex urbe ne tantum quidem, quo lateat infans. quem locum fraudi legam?

From that wasted city enough survives not even to hide a child. What place can I choose for my fraud? ${ }^{15}$

As the above-mentioned passages clearly show, the first phase of Andromache's deceit consists in the practice of concealment, strongly recommended by Hector's ghost (452-453): see occulam (477) and lateat (482). ${ }^{16}$ For it to succeed, Seneca stresses the importance of fides for the fraudatrix, i.e. her necessity to rely on someone or something in order to ensure that the fraus is successful. In fact, Andromache is looking for a locus fraudis (482), which is fidus as well (476), and ultimately, she will choose the cinus of her dead husband, literally his 'ashes', metonymically his 'tomb', inasmuch as it can be considered fidelis ( $5 \mathrm{O2}$ ), a 'safe' place, not exposed to danger or risk and, what is more, 'trustworthy' as Hector was. ${ }^{17}$

In this regard, if Andromache names her deceit fraus (loci) at 482, the old servant defines it as dolus at 492 (amoue testes doli, 'remove the witnesses to the deceit'). But at this stage, both of them refer only to the concealment of Astyanax in his father's tomb. However, Andromache's deception does not result merely in concealing.

In the development of the deceit, the old servant plays a significant role by pointing out the major element of the fraus:

\section{[3] Seneca Troades 489-49o}

haec causa multos una ab interitu arcuit: credi perisse.

One cause has saved many from destruction: the belief that they have perished. ${ }^{18}$

15 For the translation of this passage, we follow Boyle (1994), except for the translation of quem locum fraudi legam? (Boyle 'Where can I choose?').

16 Fabre-Serris (2015: 109).

17 Note that Hector's ghost himself calls Andromache fida coniunx, 'trustworthy wife' (453).

18 The translation of this passage is taken from Miller (1917). 
So the only chance of Astyanax to survive is to be supposed dead. This statement reveals that the main purpose of fraus is to affect and redirect the interpretative act of the receiver (i.e. his fides), to lead him to believe in the alternative reality the fraudator has shaped. In fact, the Latin credere ('to believe') is frequently considered to be the corresponding verb to fides, or at least as a word linked to its semantic field, given that fides is the actio uel facultas credendi siue confidendi ('the action or the property of believing and trusting').${ }^{19}$ Hence, the tragic representation of the first phase of Andromache's fraud leads us to reconsider the traditional meanings of fraus and dolus that we have provided above, by supplementing them with the notion of fides. More suitably, we can claim that fides is strictly involved in the dramaturgical frames of deceit, inasmuch as it acts on the victims' property or capacity of believing and trusting. In this view, deceits can be intended as damaging and cunning practices of simulation consisting of re-addressing, obtaining, or manipulating fides.

From the beginning, however, Andromache is presented as a fraudatrix doomed to fail because of her inability to hide her true state of mind. Even the servant (senex) does not seem to trust his mistress. That becomes evident when he suggests she move away: for otherwise, she might reveal the location of Astyanax's hideout by means of her non-verbal language and compromise the deceit by clearly showing her timor:

\section{[4] Seneca Troades $513-518$}

Sen. quem ne tuus producat in medium timor, procul hinc recede teque diuersam amoue.

An. leuius solet timere, qui propius timet; sed, si placet, referamus hinc alio pedem.

Sen. cohibe parumper ora questusque opprime: gressus nefandos dux Cephallanum admouet.

Old Man To stop your own fear from exposing him, step back from here and hold yourself apart.

An. Proximity of danger reduces fear. But, if you advise it, let us withdraw.

19 On this definition of fides, see Fraenkel (1926: c. 663, c. 686-687). On the meaning of fides as 'confidence', i.e. the fact of trusting someone or something, see also Scolari (2016: 112-114, 2018b: 91-96); Fraenkel (1916: 187-188); Hellegouarc'h ( ${ }^{2}$ 1972: 33); Benveniste (1969: I 115-121); Freyburger (1986: esp. 37-39, 319-320). 
Old Man Silence for a moment; stop your laments. Cephallenia's cursed chief approaches.

The senex begs Andromache to 'manage the impact' of her use of space (see 514), to be quiet (cohibe parumper ora), and to muffle her cries (517 questusque opprime), i.e. to reset or, at least, to control her verbal and non-verbal communication. In other words, he is concerned that Ulysses may decode Andromache's kinesic and paralinguistic signals (her lament, her weeping, etc. ${ }^{20}$ as well as her proxemic behaviour (her use and perception of space) because-as Andromache herself states, attempting a sort of kinesic exam on him (see [5])—Ulysses is a man who is accustomed to weaving cunning wiles:

\section{[5] Seneca Troades $5^{22-523}$}

An. adest Vlixes, et quidem dubio gradu uultuque: nectit pectore astus callidos.

An. Ulysses is here-with hesitant step and expression. His mind weaves some cunning trick.

Seneca here uses two other words of the semantic area of fraus: astus 'the craft', which implies the idea of 'sharpness', ${ }^{21}$ and callidus. As far as the latter is concerned, according to Cicero (Nat. D. 3.25), callidos ('hardy') are 'those whose minds have become shrewd with use as the hand is hardened and has become callous by work' (quorum, tamquam manus opera, sic animus usu concalluit). ${ }^{22}$ calliditas, astus, and the 'weaving' motive (nectere) thus co-operate to define the portrait of a consummate, gifted deceiver, who is not easily fooled. ${ }^{23}$

20 The kinesic system is one of the semiotic systems of non-verbal communication and it entails the interpretation of the body's movements such as facial expressions and gestures, including tears, as demonstrated by Ricottilli (2018a: esp. 145-147), who also highlights the relational connotation of the tears in Latin theatre, specifically in Terentius. See also Capponi in this volume.

21 Lewis and Short (1879: s.v. astus).

22 The translation is mine. On callidus, which it is said from callum ('callus'), see Ernout and Meillet ( ${ }^{4} 1985$ : s.v. callum).

23 See Michelon (2015: 24-27), who highlights in n. 23 that astus and the verb calleo ('to be callous') are already related to Ulysses by Accius, if Neopt. $184 \mathrm{D}$ (satin astu et fallendo callet?) refers to him, which seems very likely. 


\subsection{Scrutare matrem: Encoding and Decoding fraus}

If - in Attic tragedy - Ulysses is the one who convinces the Greeks that Astyanax must be killed (Eur. Tro. 721), in Seneca's drama, his step is hesitating (522 dubio gradu) and he introduces himself as a mere 'minister of harsh fate' (524 durae minister sortis). In fact, when the king of the Cephallenians comes onto the stage, he performs a very sophisticated suasoria, through which he tries

1) to remove all sense of responsibility from himself: ore quamuis uerba dicantur meo, non esse credas nostra: Graiorum omnium procerumque uox est, 'though these words are spoken by my mouth, you do not believe them mine. It is the voice of all the Greeks and chiefs' (525-527); hanc fata expetunt, 'him fate demands' (528); augur haec Calchas canit, 'so teaches Augur Calchas' (533).

2) to bridge the relational gap between Andromache and himself. Therefore, he does not hesitate to call her by name (531 Andromacha) and to use the possessive adjective to refer to Astyanax (natus [...] uester, 532-533) in order to pursue the goal of bringing her closer.

3) to induce a feeling of empathy by showing the convergence between the Phrygians' doom and what the Greeks have already suffered: neue crudelem putes, quod sorte iussus Hectoris natum petam: petissem Oresten. patere quod uictor tulit, 'don't think me cruel for seeking Hector's son commanded by the lot. I'd have sought Orestes. Accept what the victor bore' (553-555).

Therefore, from Ulysses' first speech, the conjunction emerges between emotive and conative function (the latter in a less emphatic form). The emotive function relates to the speaker and it focuses on his internal, emotive state or condition, while the conative function entails a communication or a linguistic act aiming at persuading the addressee, acquiring his adhesion to the message provided or influencing his behaviour. In the considered texts, the emotive function is used in order to activate the conative one, which is marked by the use of the imperative forms (e.g. non credas, ne putes), the vocative case Andromacha, and the possessive adjective uester. ${ }^{24}$ In other words, in order to persuade Andromache to hand over her son, Ulysses tries to connect the illocutionary act (which has a certain 'force' in saying something) with the perlocutionary act (which consists in the achieving of certain effects by saying something). ${ }^{25}$ But her reaction is not what he had hoped for.

24 On the functions of language, see Jakobson ( ${ }^{3} 1981$ : esp. 191 = 1960: 357 ).

25 On the theory of linguistic acts, and notably on the definitions of the illocutionary and perlocutionary act, see Austin ( ${ }^{2} 1975$ : esp. 126). 
[6] Seneca Troades $55^{6-558,} 5^{62-566}$

An. utinam quidem esses, nate, materna in manu, nossemque quis te casus ereptum mihi teneret $[\ldots]$ nate, quis te nunc locus, fortuna quae possedit? errore auio uagus arua lustras? uastus an patriae uapor corripuit artus? saeuus an uictor tuo lusit cruore?

An. O that you were in your mother's arms, my son, or that I knew what chance stole and keeps you from me [...]. My son, what place now, what fortune holds you? Do you wander the fields lost? Or has our country's vast conflagration consumed you? Did the savage victor sport with your blood?

Hector's widow responds with a sort of 'closing attitude', conveyed in pragmatic terms by the anaphora of the personal pronoun of the second person $(t u)$ and the possessive $t u o$, which always refers to Astyanax and never, in this passage, to Ulysses, her interlocutor. The use of this marker reveals that she is not inclined to activate a positive mutual communication with him. After the death of Hector, the only relationship she cares about is with her son, as the use of the personal pronoun mihi in the clause quis te ereptum mihiteneret stresses, combined with the vocative nate, very close to materna at 556 , both placed twice in emphatic positions. In this way, Seneca marks the emotive function of Andromache's locutionary act. However, Ulysses does not fall for her trickery:

[7] Seneca Troades $568-571$

simulata remoue uerba; non facile est tibi

decipere Vlixem: uicimus matrum dolos

etiam dearum. cassa consilia amoue;

ubi natus est?

Drop this pretence. You won't find it easy to fool Ulysses. I've beaten mothers' tricks, goddesses' too. Forget your futile ploy. Where's your son? 
Simulata remoue uerba, 'stop it with these false speeches'. Here, Ulysses has openly switched to the conative function of language because of the failure of the emotive one. ${ }^{26}$ In other terms, his locutionary act by which he tries to convince Andromache to hand over Astyanax has not achieved its perlocutionary intent since it has no effects. Nevertheless, Ulysses highlights a flaw in Andromache's deceptive system: the fact that she encodes her fraus - or rather her simulatio, i.e. her 'falsely assumed appearance' as we have said above ${ }^{27}-$ only on a verbal level, merely by means of a locutionary act (simulata uerba). He reminds her whom she is dealing with, namely the master of tricks and manipulation, and thereby evokes the literary memory of this character: that of the hero who has already unmasked a mother's fraud, not just anyone's but a goddess.' ${ }^{28}$ Here, Ulysses is referring to the doli of Thetis, who dressed and disguised her son Achilles as a girl, determined to keep him out of the war that would have caused his death. ${ }^{29}$ Thus, Ulysses' statement allows a key component of the fraud to emerge: the importance of becoming aware of the identity role of the interlocutor, if one wishes to perform a successful fraus.

Andromache, however, does not seem to care about the identity role of Ulysses or about his story. Even if she knows his reputation, she seeks to deceive him by using a strategy similar to his:

\section{[8] Seneca Troades 594-597}

inuita, Vlixe, gaudium Danais dabo.

dandum est. fatere quos premis luctus, dolor.

gaudete, Atridae, tuque laetifica, ut soles,

refer Pelasgis: Hectoris proles obit.

I hate, Ulysses, to give the Danai joy. Yet I must. Confess the sorrow you hide, grief. Gloat, sons of Atreus. You, take the Pelasgi, as usual, joyous news: Hector's child is dead.

Firstly, Andromache does not avoid naming him (see the vocative Vlixe in 594) to close the gap between them; secondly, she attempts to provide an alternate

\footnotetext{
26 See above n. 24.

27 See Section 1.

28 On the traditional representation of Ulysses as master of deceits underlined by Seneca in [7], see Michelon (2015: 27-28).

29 See Sen. Tro. 213 and Boyle (1994: ad loc.).
} 
reality, which can meet the Greek's expectations, as can be seen from the use of the semantic field of delight and joy: gaudium, gaudete, laetifica, etc. (in opposition to the field of dolor). Once again, Ulysses demands a concrete guarantee, which is able to ensure that what Andromache said is true:

\section{[9] Seneca Troades 598}

et esse uerum hoc qua probas Danais fide?

What proof do you give Danaans that this is true?

The question asked by Ulysses in this line brings the paretymology of fraus into play that is provided by Cicero (Off.1.23), according to whom fides comes from fiat and dico, because it implies that what you do matches what you said you would do, namely that there is no discrepancy between words and deeds: quia fiat, quod dictum est appellatam fidem, 'fides ('trust') is called this because one does what he has said'.30

But Andromache has no such proof, so instead of a tangible guarantee, she swears, to some extent, an assertory oath (599-604) to prove that Astyanax lies with dead men', inter extinctos iacet (603). And we know that assertory oaths in the ancient world were serious business since an oath was considered a selfcurse, inasmuch as oath-takers placed themselves directly under the threat of divine punishment, which everyone believed would surely be imposed on the perjurer. ${ }^{31}$ Ulysses stresses that the oath represents a guarantee of mutual fides ( fidem alligauit iure iurando suam, si peierat, timere quid grauius potest?, 'she had pledged her faith by swearing an oath. If she swears falsely, what worse can she fear?', 611-612). He is convinced that the Greeks will trust him, but the point is whom Ulysses trusts.

\section{[10] Seneca Troades 6o7-6o9}

Vl. quid agis, Vlixe? Danaidae credent tibi: tu cui? parenti? fingit an quisquam hoc parens, nec abominandae mortis auspicium pauet?

30 On this passage, see Dyck (1996: ad loc.). See also Cic. Rep. 4.7 (fr. 2.5-6) fides enim nomen ipsum mihi uidetur habere, cum fit, quod dicitur, 'for it seems to me that fides is called this because one does what he says'.

31 See Lecointre (1991: 9-10); Pageard (1991: 35); and Benveniste (1969: II 163-164). 
Ul. (Aside) What's this, Ulysses? The Danai will trust you. But you trust - a mother? Would any mother lie and not fear omens of frightful death?

Unlike Andromache, Ulysses asks himself about the prominent identity role of his interlocutor in the very context and in the very moment of their dynamic of communication: above all, she is a mother, as the polyptoton parenti / parens points out (6o8). This is her predominant role. The persona of Ulysses derives this information from Andromache, who implicitly introduces herself as a mater animosa, 'a dauntless mother', who 'admits no fears': animosa nullos mater admittit metus (588). Therefore, the only type of fides she can express is materna fides: maternam fidem umquam exuissem, 'I would never put off a mother's loyalty' (561-562).

\section{[11] Seneca Troades 613-618}

nunc aduoca astus, anime, nunc fraudes, dolos, nunc totum Vlixem; ueritas numquam perit. scrutare matrem: maeret, illacrimat, gemit; sed huc et illuc anxios gressus refert missasque uoces aure sollicita excipit: magis haec timet, quam maeret. ingenio est opus.

Now summon your guile, my soul, now tricks, deceits, now all Ulysses; truth is never lost. Examine the mother. She mourns, weeps, groans, but paces her anxious steps up and down and strains her troubled ears to pick up sounds. She's more afraid than grieving. We need our wits.

Thus, Ulysses sets out to examine Andromache's non-verbal communication, paying particular attention to her parental role (615 scrutare matrem).$^{32}$ In other words, he intends to make a pragmatic analysis of the non-verbal forms of her behaviour in order to assess their compliance with Andromache's locutionary act. In order to achieve this, he needs 'all of Ulysses', the entire master of manipulation and deceits: not surprisingly, he calls astus, fraudes and dolos (613) into question since he is convinced that they are especially apt not only for 'encoding' deceits and frauds but also for decoding them. On the other hand,

32 On the investing gaze of Ulysses, see Benton (2002: 34-35). On the meaning of scrutari, see OLD, s.v.: 'to look searchingly at', 'scan', 'scrutinize'. 
there is no part of him which completely exemplifies the characteristics of his persona - this is summed up in a single word at the end of the passage: ingenium (618), his 'innate quality'. It is evident that this is once again an implicit mention of the literary memory of this mythical character, of his identity features, and dramaturgical function. In fact, Ulysses is able to identify:

- paralinguistic features (within which all the meta-communication components are included, such as gasps and sighs) and kinesic signals (if we accept tears as gestures): ${ }^{33}$ maeret, illacrimat, gemit.

- proxemic communication and kinesic signals: sed huc et illuc anxios gressus refert.

- prosodic features, like the empty pause (the silence) of Andromache, which conveys her suspense, worry and anxiety (cf. sollecita), and the consequent chronemic signals, which reveal an irregular, non-fluent communication flow: ${ }^{34}$ missasque uoces aure sollicita excipit.

The decoding of Andromache's non-verbal communication, on all levels, conveys a discrepancy between words and paralinguistic, kinesic and proxemic language. In other words, the outcome of the decoding act is that Andromache magis [...] timet, quam maeret (618). Therefore, by his pragmatic investigation, Ulysses manages to detect that the prominent feeling of his interlocutor is fear.

\subsection{The Counter-Fraud}

After decoding fraus and individuating the weakness of Andromache (her timor), which emerges very clearly from her mimic, gestures, and non-verbal behaviour, Ulysses decides to reply with a sort of 'counter-fraud' to test his own interpretation. We will use this term on the basis of 'counter-gift', in so far as fraus is a perlocutionary act ${ }^{35}$ that belongs to the mechanism of negative reciprocity, consisting precisely in a dramaturgical pattern of iniuria (the 'offence') and ultio (the 'revenge'). ${ }^{36}$ Furthermore, we have already noted that iniuria is linked to the semantic field of fraus. ${ }^{37}$ Ernout and Meillet explain it as 'tort fait à quelqu' un', 'dommage', i.e. the same meaning as that of iniuria, ${ }^{38}$ 'et par suite "fraude, tromperie"':

33 On the kinesic system and tears classified as gestures, see above n. 20 and Calabrese in this volume.

34 For an analysis of the relationship between prosody and gesture, see Wharton (2009: 139149).

35 See Austin ( $\left.{ }^{2} 1975: 101-108\right)$.

36 See Courtois (1984: 109-124).

37 See Section 1.

38 See Scolari (2018a: 136-139). See also Manfredini (1977: esp. 135) and Krause (2006: $83=$ 2004: 90). 
Comme le dommage s' accompagne généralement de manœuvres dolosives, fraus est arrivé à signifier 'ruse, tromperie, fourberie' et même 'piège' dans la langue familière. ${ }^{39}$

Therefore, the mechanism of fraus works along the same principles as exchange, and notably gift-giving practices, but antithetically. In fact, iniuria is the first stage of the revenge system in that it upsets the beneficium process (and, more generally, the process of gift-giving); ${ }^{40}$ revenge, in a second step, constitutes the antithesis to gratitude and the 'counter-gift'. ${ }^{11}$ In this respect, Cicero reports a definition of iniuria, which confirms that even fraus forms part of the negative reciprocity systems as one of the two patterns of 'injustice' (iniuria), which is the most contemptible:

\section{[12] Cicero De officiis 1.41}

cum autem duobus modis, id est aut ui aut fraude, fiat iniuria, fraus quasi uulpeculae, uis leonis videtur; utrumque homine alienissimum, sed fraus odio digna maiore.

There are two ways in which injustice may be done, either through force or through deceit; and deceit seems to belong to a little fox, force to a lion. Both of them seem most alien to a human being; but deceit deserves a greater hatred. ${ }^{42}$

The counter-fraud of Ulysses consists in revealing the harsh truth (a strategy that complies with his sentence ueritas numquam perit [614]), by underlining the nature of the Astyanax's death decreed by the Achaeans, in order to intensify mother's emotions: ${ }^{43}$ quem mors manebat saeua praecipitem datume turre, lapsis sola quae muris manet, 'a savage death awaited him, hurled headlong from the only tower those ruined walls still have' (621-622). In the aside, which has a didascalic function, Andromache allows her non-verbal signals of fear to emerge:

39 Ernout and Meillet $\left({ }^{4} 1985: 25^{2}\right.$ s.v. fraus $)$.

40 Discussed more fully in Scolari (2018a: 136-142, 195-207).

41 In this regard, see Gouldner (196o: 169); Verdier (1980a: 30, 1980b: 11); Seaford (1998: 1); van Wees (1998: 24).

42 For the translation, see Griffin and Atkins (1991).

43 See Fabre-Serris (2015: 110-111). 
[13] Seneca Troades 623-631

An. reliquit animus membra, quatiuntur, labant! torpetque uinctus frigido sanguis gelu.

Vl. intremuit. hac, hac parte quaerenda est mihi. matrem timor detexit. iterabo metum. ite, ite celeres, fraude materna abditum hostem, Pelasgi nominis pestem ultimam. ubicumque latitat, erutam in medium date. bene est: tenetur. perge, festina, attrahequid respicis trepidasque? iam certe perit.

An. (Aside) Life seeps from my limbs. They quiver, give way. My blood congeals, bound fast by freezing ice.

Ul. (Aside) She trembled. This, this is where I must probe. Fear unmasked the mother. I'll double that fear. (Aloud) Go, go, men! Quickly! A mother's trick hides our enemy, the Pelasgians' last blight. Wherever he hides, root him out, bring him here! Good, we have him! Hurry, quick, drag him here-(To Andromache) Why look back and tremble? Surely he's now dead.

By decoding her uncontrolled trembling (625 intremuit), Ulysses can deduce that 'fear has unmasked the mother' (626 matrem timor detexit). By manipulating Andromache's emotions, Seneca's character proves that he has mastered the rhetorical art of persuasion, which lies in provoking the feelings useful to achieve the desired effect (Cic. De or. 2.115) ${ }^{44}$ In order to decode materna fraus (627), he clearly knows that he has to consider the parental role of Andromache more than any other aspect of her identity. Furthermore, he does not overlook to observe her eye movement attentively: quid respicis trepidasque? [12]. respicere signifies 'to look back' and it is properly applied to express the action of turning the head back to look at something or someone. ${ }^{45}$ As stated by Bettini, this verb also communicates the willingness to have contact or rather to take someone into account. ${ }^{46}$ Hence, Andromache's action

44 See also Arist. Rhet. 1356a4, 14-15, 20-25; Cic. De or. 1.17, 178; Quint. Inst. 1.2.30, 1.6.2. On the link between persuasive strategies and the manipulation of emotions in classical antiquity, see Sanders and Johncock (2016).

45 See Marchese (2016: 14-22).

46 Bettini ( $\left.{ }^{2} 1988: 135\right)$. 
of respicere is a kinesic signal that allows Ulysses to find Astyanax and to thwart his mother's plans.

When it is too late, all of a sudden, Andromache remembers whom she is dealing with, a machinator fraudis et scelerum artifex, 'genecist of deceit, craftsman of evil' (750), and she recognises the specific identity of Ulysses and the natural inclinations of his malefica mens (752), demonstrated by dolus and astus.

We can claim that from the very beginning of the tragedy Seneca's Andromache shows her incompatibility with the fraudator profile. In the hiding scene, she is portrayed as incapable of decoding non-verbal signals of her own son, when she interprets his fear as shame:

\section{[14] Seneca Troades 503-505}

An.

$$
\text { quid retro fugis }
$$

turpesne latebras spernis? agnosco indolem:

pudet timere.

An. Do you shrink back, spurn base refuge? I recognise your breeding: You're ashamed of fear.

She seems to be convinced of her ability to recognise Astyanax's proxemic and kinesic signals as hereditary traits (agnosco indolem), but, as stressed by Ulysses, 'grief is no impartial judge of things', est quidem iniustus dolor rerum aestimator (545).

But the failure of her tricks notably depends on the disregarding of the receiver's identity and his dramaturgical role, although the real value of Ulysses is well known: uirtus Vlixis [...] nota est satis (757). We could say that Andromache does not follow the advice that Thyestes, in the homonymous tragedy, gives to himself: cum quod datur spectabis, et dantem aspice, 'when you view a gift, look at the giver, too' (Thy. 416$).{ }^{47}$

47 For the translation of Seneca's Thyestes, we follow Boyle (2017), except where otherwise noted. Tarrant (1985: 151 ad 416) stresses that this sententia is grounded in symmetrically balanced nouns and verbs-quod datur-dantem, spectabis-aspice. But, at least, it will be Atreus who looks carefully at Thyestes: see 505 aspice. 


\section{Pragmatics of fraus in Thyestes}

\subsection{Post fratris dolos: Outrage and Revenge}

In Thyestes as well, the fraus practice seems to be related to a dynamic of negative reciprocity. ${ }^{48}$ We can note that much when we take into account the dialogue between Atreus and his attendant (satelles), in which Atreus states that his revenge will be performed post fratris dolos (178) and the anaphora of fraus at 224 ( fraude est adeptus, fraude turbauit domum, by fraud he filched our ancient mark of power, by fraud confounded our house'), which refers to the dramaturgical and pragmatic pattern of iniuria committed by Thyestes against his brother. Moreover, at the end of the drama, Atreus represents the ultio carried out by the fraus as a way to repay his brother for his crimes: sceleri modus debetur ubi facias scelus, non ubi reponas, 'evil has due measure when evil's done, not when it's avenged' (1052).49 Therefore, with his fraus, Thyestes has betrayed Atreus' fides first: in fact, the latter calls him perfidus (235), which indicates 'someone who breaks his promise', who has overturned the bond ensured by fides. ${ }^{50}$ Indeed, at 239, Atreus deplores that the imperi fides, i.e. his 'guarantee about the power', is disrupted (quassa est). ${ }^{51}$

Unlike Andromache, Atreus claims knowledge of the innate quality of Thyestes (noui ego ingenium uiri, indocile, 199-200), his untameable nature, and, consequently, his weakness. Therefore, in the light of this boon, grounded on 'relational knowledge', he will be able to lead Thyestes himself to cause his own ruin: quod est in isto scelere praecipuum nefas, hoc ipse faciet, 'the principal horror in this crime-he will perform himself' $\left(285^{-286}\right) .{ }^{52}$ The perlocutionary effect that Atreus intends to achieve with his fraus resides in this very aim, for which the knowledge of the interlocutor's disposition is essential:

[15] Seneca Thyestes 286-295

Sat.

sed quibus captus dolis

nostros dabit perductus in laqueos pedem?

\footnotetext{
48 See Paduano (1988-1989: 296).

49 On the topic of measure (modus) and on the maius-motif of revenge in Seneca's tragedies, see Schiesaro (2003: 130).

50 See Ernout and Meillet ( ${ }^{4} 1985$ : s.v. fides): '"perfide", que l' on explique par qui per fidem decipit (Plt., Mo. 50o, per fidem deceptus sum), mais où per- peut marquer la déviation'.

51 Picone (1984: 12, 61-66).

$5^{2}$ On Atreus as a machinator doli, see Picone (1984: 65).
} 
inimica credit cuncta. At. non poterat capi, nisi capere uellet. regna nunc sperat mea: hac spe minanti fulmen occurret Ioui, hac spe subibit gurgitis tumidi minas dubiumque Libycae Syrtis intrabit fretum, hac spe, quod esse maximum retur malum, fratrem uidebit. Sat. quis fidem pacis dabit? cui tanta credet? At. credula est spes improba.

Att. What tricks will draw his feet into our snares? He thinks the worlds his foe.

Atr. He couldn't be taken unless he aimed to take us. He hopes for my kingdom still. In this hope he'll meet Jove's menacing bolt, in this hope he'll face threats of swelling seas and enter Lybian Syrtes' dubious shoals. In this hope- to him the greatest trial—he'll see his brother.

Att. Who'll assure the peace? Whom will he trust on such things?

Atr. Vile hope trusts all.

Atreus underlines his intent of encoding a deceptive message able to meet the 'unfair expectation' (295 spes improba) of Thyestes (emphasised by the anaphora of hac spe at 290, 291, and $293^{53}$ ), who hopes to obtain Atreus' kingdom (289 regna nunc sperat mea). Though the courtier stresses the necessity to provide a tangible guarantee of peace ( fides pacis), Atreus has no reason to worry, because, focusing on the specific weakness of the victim of the fraus, he knows that it consists in his credulitas (namely an excess of fides): credula est spes improba (295). However, during the entire play, Thyestes has a presentiment regarding the oncoming deceit ${ }^{54}$ and urges himself not to trust his brother, who is described as a res incertissima alongside power (424-425 rebus incertissimis, fratriatque regno, credis ...?, 'do you trust the most faithless things, brother and throne?'). Moreover, he labels his heart as 'credulous' or-more suitably-'deluded' in the apostrophe at 963: credula praesta pectora fratri, 'offer your deluded heart to the brother. ${ }^{55}$ In this sentence, the adjective credu-

53 I follow Boyle (2017) and Fitch (2004: ad loc.); Tarrant (1985: ad loc.) and Zwierlein ( ${ }^{3} 2009$ : ad loc.) move 290 to after 292 . On the motive of spes regni as a trap against Thyestes, see Picone (1984: 61).

54 See Thy. 472-473, 482-484.

55 For the sense of credulus as 'deluded', 'too trusting', I follow Traina (1981: 131-132), who 
lus underscores the danger of excessive trust placed in Atreus. As Traina has noted, the opposition between the syntagm praesta and the semanteme credulum encapsulates the conflict between the two main themes in the monody: the will, voice of consciousness, and the premonition, voice of subconscious. ${ }^{56}$ Nevertheless, Thyestes proves unable to escape Atreus' fraus that is performing as a trap (see [15] for the use of captus and laqueos), for which the signifier of 'piège', provided by Ernout and Meillet, ${ }^{57}$ is more than appropriate.

Praestetur fides: The Performance of fraus between Encoding and Decoding Acts

[16] Seneca Thyestes 504-511

cum sperat ira sanguinem, nescit tegitamen tegatur. aspice, ut multo grauis squalore uultus obruat maestos coma, quam foeda iaceat barba. praestetur fides. fratrem iuuat uidere. complexus mihi redde expetitos. quidquid irarum fuit transierit. ex hoc sanguis ac pietas die colantur, animis odia damnata excidant.

When anger smells blood, it won't be hidden-yet hidden it must be. Look how matted, filthy hair overwhelms his gloomy face, how foul his drooping beard. Now for a show of faith. (To Thyestes) Brother-it's a joy to see you. Give me the hug I've longed for. (They embrace) What anger existed let it be gone. From this day let's cherish blood and family piety, rid out hearts of damned hate.

The 'encoding of the fraus' scene is divided into two brief dramaturgical moments, an aside and the proper dialogue between the brothers. In the first frame of the scene, Atreus notes the squalor of his brother, caused by his exile, the principal reason of his weakness, and suggests to himself to conceal his wrath and to be believable (507 praestetur fides), i.e. to provide evidence of

examines the occurrences of this term in Seneca's corpus from a semantic point of view to provide a more accurate translation.

56 Traina (1981: 132).

57 See supra, n. 39. 
his credibility to perform a non-verbal behaviour, which works as a 'display of loyalty'.58 The second part of the fraus act reveals not only a didascalic but a pragmatic function as well: the opening utterance fratrem iuuat uidere is not only an illocutionary act, but it also conveys some information about the kinesic and mimic signals that Atreus manipulates to affect the interpretation act of Thyestes. ${ }^{59} \mathrm{He}$ pretends to be glad to see his brother, and he asks him for a hug, involving even the haptic level of communication in the encoding of the fraus. The physical contact implied makes this an interaction entailing touch. ${ }^{60}$ He also provides to Thyestes a proof of loyalty, showing his intention of restoring (reddere) the paternum decus (528) to his brother, i.e. the crown and sharing the power with him.

This dynamic takes the form of a gift: Seneca represents the simulatio of forgiveness performed by Atreus as a mechanism of positive reciprocity ${ }^{61}$ aimed to overturn the nature of their relationships: from hostility and hatred into a positive reciprocity exchange. Even if Seneca does not use the verb simulare, the strategy of Atreus' fraus complies to its meaning: 'a falsely assumed appearance' and 'a kind of pretence regarding [...] mental states', or rather, 'regarding relational dynamic' as gift-giving. ${ }^{62}$ By the expedient of the simulated gift, Atreus is able to close the gap between his brother and himself (in this case, both relational and physical), taking advantage of the fascinating power of the gift, which is already described by Renata Raccanelli as 'il metalinguaggio analogico della relazione', or (more suitably) 'la comunicazione della proposta di comunicare.' 63

Thyestes does not waste any time: accipio, he says, 'I accept' (542). The same concept will be repeated in a different form at 983-984 with reference to the cannibalistic banquet provided by Atreus, which is ultrix daps (894) as well:

$5^{8}$ Even if this frame is generally regarded as an aside, it may imply an audience, i.e. a role that the satelles could play, even if his entry is not explicitly marked. On the presence on stage of minor characters, see de Jong (2007: 7-9) and Taplin (1977: 8). On aspice as a metatheatrical invitation to the real audience, see Boyle (2017: ad loc.).

59 Di Raimo (2019: 317-318) argues that Atreus simulates the reasons of his glee but not the feeling itself (conveyed by the verb iuvat): the awareness of approaching revenge makes the character delighted. See also the use of iuuat at 1101.

6o Atreus asks the same to his nephews in 521-524 a genibus manum aufer meosque potius amplexus pete. uos quoque, senum praesidia, tot iuuenes, meo pendete collo.

61 See the above-mentioned 416 cum quod datur spectabis, et dantem aspice, 536 dona fortunae, and 984 donum dapis.

62 See Section 1. See also Ernout and Meillet ( ${ }^{4} 1985$ : s.v. similis: 'simulo: [...] "faire semblant de"').

63 Raccanelli (2011: 307-309). 
capio fraternae dapis donum. ${ }^{64}$ Hence, Seneca uses a performative and complementary couple of verbs (reddere/accipere). ${ }^{65}$ The latter allows Thyestes 'to do things with words', namely to obtain the crown that Atreus puts on his head but, at the same time, to get caught.

Thus, in Thyestes, the decoding act is carried out by the fraudator himself since it belongs to the deceptive practice. Furthermore, Atreus has already clarified that he does not want to see him broken, 'but to see him being broken' (907 miserum uidere nolo, sed dum fit miser). ${ }^{66}$ In this purpose, the acknowledgement scene in which the ultor can reveal his fraud is an essential part of the revenge:

[17] Seneca Thyestes 1004-1005

Atr. $\quad$... natos ecquid agnoscis tuos?

Thy. agnosco fratrem.

Atr. ... I suppose you recognise your sons?

Thy. I recognise my brother.

\section{4}

\section{Conclusions}

As we sought to illustrate in this survey, in the plays considered, Seneca makes extensive use of the semantic field of deceit, especially of fraus and dolus. The latter is mostly used in the plural (see Tro. 213, 569, 613; Thy. 178, 286, 318) and, apparently, not only for metrical reasons. fraude materna [13, line 627], for instance, corresponds to matrum dolos [7, line 569] (not to the singular dolus); and fratris dolos (178) and fraude at 224 relate to the same deceit. ${ }^{67}$ Hence, we can argue that, even if Seneca employs fraus and dolus almost interchangeably, he prefers to use fraus to convey a more complex and sophisticated strategy of deception, in so far as dolus is apparently considered as a 'softer', less structured deceit.

\footnotetext{
64 See Mazzoli (2016: $341-35$ ).

65 On performative utterances, see Austin ( ${ }^{2} 1975$ : esp. 6-8, 25-36). On performativity applied to Latin literature, see Anscombre and Pierrot (1985).

66 Here I follow Fitch (2004).

67 See also fraudem (Thy. 316) and dolos (Thy. 318) that refer to the same deception. The only occurrence of the singular dolus in Thyestes is in 773: errat hic aliquis dolus, which can be more suitably translated as 'here there is some kind of deceit'.
} 
However, the success of fraus (and dolus) within the communication event represented in Seneca's two tragedies which we have examined (but we might as well widen the scope of our investigation), depends mainly on:

- knowledge of the interlocutor: the fact of having regard to his/her identity role, desires and weaknesses;

- credulitas of the receiver, or simply their willingness to trust (credere) the fraudator; conversely, the fraudator's ability to manipulate his interlocutor's fides;

- compliance between verbal and non-verbal communication;

- ability to manipulate relational contexts.

Therefore, in order to furnish a definition of fraus from a pragmatic and anthropological point of view, we can define fraus as a mimetic and performative act, which underlies 'a falsely assumed appearance' and 'a kind of pretence regarding [...] mental states' or 'relational dynamic' (the proper sense of simulatio provided in Section 1) with perlocutionary intent, i.e. the purpose of achieving certain effects, specifically of influencing someone's actions or forms of behaviour by saying something. This performative act forms part of the negative reciprocity system of iniuria and aims at driving the interlocutor's belief (his fides, taking advantage of his credulitas) and redirecting his interpretative acts, by means of the compliance between verbal and non-verbal communication, as well as the ability of the fraudator to manipulate the relational contexts, in order to provide tangible evidence to enforce the trustworthiness of the deceptive message.

\section{Acknowledgements}

I am grateful to Federica Iurescia, Giada Sorrentino, Severin Hof, and Gunther Martin for their generous commitment, constructive suggestions and support. I also wish to thank all the conference attendees for stimulating discussions that helped formulate this paper.

\section{References}

Abbot, J.C., (1997), Roman Deceit: Dolus in Latin Literature and Roman Society (Roman Republic, Roman Empire), PhD thesis (University of North Carolina at Chapel Hill).

Anscombre, J.C. \& Pierrot, A., (1985), 'Sulla performatività in latino', Paideia 40, 35-47. Austin, J.L., ( $\left.{ }^{2} 1975[1962]\right)$, How to Do Things with Words, Oxford/London. 
Barney, S.A., Lewis, W.J., Beach, J.A., \& Berghof, O., ( ${ }^{4} 2008$ [2006]), The Etymologies of Isidore of Seville, Cambridge.

Bateson, G., (1972), Steps to an Ecology of Mind, San Francisco.

Benton, C., (2002), 'Split Vision: the Politics of the Gaze in Seneca's Troades', in D. Fredrick (ed.), The Roman Gaze. Vision, Power and the Body, Baltimore, 31-56.

Benveniste, É., (1969), Le vocabulaire des institutions indo-européennes, 2 vols., Paris.

Beta, S., (2004), La potenza della parola. Destinatari, Funzioni, Bersagli, Atti del Convegno di Studi, Siena, 7-8 maggio 2002, Fiesole.

Bettini, M., ( ${ }^{2} 1988$ [1986]), Antropologia e cultura romana, Florence.

Bettini, M. \& Ricottilli, L., (1987), 'Elogio dell'indiscrezione', Studi Urbinati/B3 6o, 11-27.

Boyle, A.J., (1994), Seneca's Troades, Leeds.

Boyle, A.J., (2017), Seneca, Thyestes, Oxford.

Brotherton, B., (1926), The Vocabulary of Intrigue in Roman Comedy, Chicago.

Calabrese, E., (2007), 'Infrazione del silenzio e uso di verba nella Fedra di Seneca', Paideia 62, 171-192.

Calabrese, E., (2009), Il sistema della comunicazione nella Fedra di Seneca, Palermo.

Calabrese, E., (2011), 'Il dono e la relazione padre-figlio nella Fedra di Seneca', in G. Picone, L. Ricottilli, \& L. Beltrami (eds.), Benefattori e beneficati. La relazione asimmetrica nel De beneficiis di Seneca, Palermo, 25-46.

Carcaterra, A., (1970), Dolus bonus/dolus malus. Esegesi di D. 43,1,2-3, Naples.

Courtois, G., (1984), 'Le sens et la valeur de la vengeance chez Aristote et Sénèque', in R. Verdier, J.P. Poly, \& G. Courtois (eds.), La vengeance. Études d'ethnologie, d'histoire et de philosophie, vol. 4, Paris, 91-124.

Di Raimo, L., (2019), 'Gioia simulata e gioia indotta. Il godimento della vendetta in Seneca tragico', in M. De Poli (ed.), Il teatro delle emozioni: la gioia, Padova, 313-326.

Duranti, A., (1997), Linguistic Anthropology, Cambridge.

Dyck, A.R., (1996), A Commentary on Cicero, De Officiis, Ann Arbor.

Ernout, A. \& Meillet, A., $\left({ }^{4} 1985\right.$ [1932]), Dictionnaire étymologique de la langue latine. Histoire des mots, Paris.

Fabre-Serris, J., (2015), 'Women after War in Seneca's Troades. A Reflection on Emotions', in J. Fabre-Serris \& A. Keith (eds.), Women and War in Antiquity, Baltimore, 100-118.

Fitch, J.G., (2004), Seneca, Tragedies, vol. 2, Cambridge, Mass./London.

Fraenkel, E., (1916), 'Zur Geschichte des Wortes fides', Rheinisches Museum für Philologie 71, 187-199.

Fraenkel, E., (1926), Fides, in ThLL 6, pars prior, F, c. 661-691.

Freyburger, G., (1986), Fides. Étude sémantique et religieuse depuis les origines jusqu'à l'époque augustéenne, Paris.

Gouldner, A.W., (1960), 'The Norm of Reciprocity: a Preliminary Statement', American Sociological Review 15, 161-178.

Griffin, M.T. \& Atkins, E.M., (1991), Cicero, On Duties, Cambridge. 
Hellegouarc'h, J., ( ${ }^{2} 1972$ [1963]), Le vocabulaire latin des relations et des partis politiques sous la République, Paris.

Hey, O., (1910), dolus, in ThLL 5, pars prior, D, c. 1857-1864.

Jakobson, R., ( ${ }^{3} 1981$ [1966]), 'Linguistica e poetica' in R. Jakobson, Saggi di linguistica generale, Milan, 181-218 (Ital. transl. of 'Closing Statements: Linguistics and Poetics', in T.A. Sebeok (ed.), Style in Language, New York 196o, 350-377).

Jong, I.J.F. de, (2007), 'Sophocles' Trachiniae, Euripidean Prologues, and their Audiences', in R.J. Allan \& M. Buijs (eds.), The Language of Literature. Linguistic Approaches to Classical Texts, Leiden/Boston, 7-28.

Krause, J.-U., (2006), La criminalità nel mondo antico, Rome (Ital. transl. of Kriminalgeschichte der Antike, Munich 2004).

Krüger, H. \& Kaser, M., (1943), 'Fraus', Zeitschrift der Savigny-Stiftung für Rechtsgeschichte, Romanistische Abteilung 63, 117-174.

Lecointre, S., (1991), 'Ma langue prêta serment', in R. Verdier (ed.), Le serment, vol. 1, Paris, $5^{-22}$.

Lewis, C.T. \& Short, C., (1879), A Latin Dictionary, Oxford.

Manfredini, A.D., (1977), Contributi allo studio dell'iniuria in età repubblicana, Milan.

Marchese, R.R., (2016), Uno sguardo che vede. L'idea di rispetto in Cicerone e in Seneca, Palermo.

Mazzoli, G., (2016), Il chaos e le sue architetture. Trenta studi su Seneca tragico, Palermo. Michelon, F., (2015), La scena dell'inganno: finzioni tragiche nel teatro di Seneca, Turnhout.

Miller, F.J., (1917), Seneca, vol. 8: Tragedies I, Cambridge, Mass./London.

Paduano, G., (1988-1989), 'La climax della volontà di potenza nel Tieste di Seneca', Quaderni di Cultura e Tradizione Classica 6-7, 287-300.

Pageard, R., (1991), 'Les sanctions du serment du mythique au logique. Du social à l' intime', in R. Verdier (ed.), Le serment, vol. 1, Paris, 35-41.

Picone, G., (1984), La fabula e il regno. Studi sul Thyestes di Seneca, Palermo.

Raccanelli, R., (1998), L'amicitia nelle commedie di Plauto: un'indagine antropologica, Bari.

Raccanelli, R., (2010), Esercizi di dono. Pragmatica e paradossi delle relazioni nel De beneficiis di Seneca, Palermo.

Raccanelli, R., (2011), 'Cambiare il dono: per una pragmatica delle relazioni nel De beneficiis senecano', in G. Picone, L. Ricottilli, \& L. Beltrami (eds.), Benefattori e beneficati. La relazione asimmetrica nel De beneficiis di Seneca, Palermo, 303-356.

Ricottilli, L., (200o), Gesto e parola nell'Eneide, Bologna.

Ricottilli, L., (2009), 'Appunti sulla Pragmatica della Comunicazione e della letteratura latina', in A. Barchiesi \& G. Guidorizzi (eds.), La stella sta compiendo il suo giro. Atti del convegno internazionale di Siracusa, 21-23 maggio 2007, Florence, 121-170.

Ricottilli, L., (2011), 'Aspetti della rappresentazione gestuale nel De beneficiis', in 
G. Picone, L. Ricottilli, \& L. Beltrami (eds.), Benefattori e beneficati. La relazione asimmetrica nel De beneficiis di Seneca, Palermo, 399-429.

Ricottilli, L., (2018a), 'Lacrime e sympatheia in Terenzio', in Ricottilli 2018b, 145-166.

Ricottilli, L., (2018b), Modalità della comunicazione in Roma antica, Bologna.

Rubenbauer, I., (1926), fraus, in ThLL 6, pars prior, F, c. 1266-1277.

Sanders, E. \& Johncock, M. (eds.), (2016), Emotion and Persuasion in Classical Antiquity, Stuttgart.

Schiesaro, A., (2003), The Passions in Play: Thyestes and the Dynamics of Senecan Drama, Cambridge.

Scolari, L., (2016), 'La fides e la promessa. Forme di reciprocità tra dèi e uomini nella riscrittura di Ovidio', Quaderni del Ramo d'Oro on-line 8, 112-127. http://www.qro .unisi.it/frontend/sites/default/files/Scolari_La_fides_e_la_promessa.pdf [11/o3/ 2020].

Scolari, L., (2018a), Beneficium e iniuria. Rappresentazioni del dono e dell'offesa nel De beneficiis diSeneca, Palermo. https://www.classicocontemporaneo.eu/PDF/379.pdf [11/03/2020].

Scolari, L., (2018b), Donifunesti. Miti di scambi pericolosi nella letteratura latina, Pisa.

Seaford, R., (1998), 'Introduction', in C. Gill, N. Postlethwaite, \& R. Seaford (eds.), Reciprocity in Ancient Greece, New York, 1-12.

Searle, J.R., (1969), Speech Acts: an Essay in the Philosophy of Language, Cambridge.

Taplin, O., (1977), The Stagecraft of Aeschylus: the Dramatic Use of Exits and Entrances in Greek Tragedy, Oxford.

Tarrant, R.J., (1985), Seneca's Thyestes, Atlanta.

Ter Beek, L.J., (1999), Dolus: een semantisch-juridische studie, Nijmegen.

Traina, A., (1981), 'Due note a Seneca tragico. La fiducia di Tieste', in A. Traina, Poeti latini e neolatini: note e saggi filologici, $2^{\text {a }}$ serie, Bologna, 130-132. (first published in Maia, 1979, 273-276).

Verdier, R., (1980a), 'Le système vindicatoire. Esquisse théorique', in R. Verdier, J.P. Poly, \& G. Courtois (eds.), La vengeance. Études d'ethnologie, d'histoire et de philosophie, vol. 1, Paris, 11-42.

Verdier, R., (198ob), 'De l'une à l' autre vengeance', in R. Verdier, J.P. Poly, \& G. Courtois (eds.), La vengeance. Études d'ethnologie, d'histoire et de philosophie, vol. 2, Paris, 713 .

Watzlawick, P., Beavin, J.H., \& Jackson, D.D., (1967), Pragmatics of Human Communication: a Study of Interactional Patterns, Pathologies, and Paradoxes, New York.

Wees, H. van, (1998), 'The Law of Gratitude: Reciprocity in Anthropological Theory', in C. Gill, N. Postlethwaite, \& R. Seaford (eds.), Reciprocity in Ancient Greece, New York, 13-49.

Wharton, T., (2009), Pragmatics and Non-Verbal Communication, Cambridge.

Wheeler, E., (1988), Stratagem and the Vocabulary of Military Trickery, Leiden.

Zwierlein, O., ( ${ }^{3} 2009$ [1986]), L. Annaei Senecae tragoediae, Oxford. 